\title{
Standard test methods applied for minimalisation of fire and explosion hazard during co-firing of biomass and coal
}

\author{
Marek Woliński ${ }^{1, *}$ \\ ${ }^{1}$ Szkoła Główna Służby Pożarniczej (Main School of Fire Service), Juliusza Słowackiego 52/54, \\ 01-629 Warsaw, Poland
}

\begin{abstract}
The use of existing coal feeding system for the input of the crushed biomass to the energy boiler requires the least expenditures to start and run a multi-fuel combustion installation. And if losing popularity technology of co-firing biomass with coal is intended to allow meeting Polish promises to achieve the $15 \%$ share of renewable energy sources in the energy mix by the year 2020 , such approach could be expected rather than construction of new, dedicated multi-fuel installations to produce electricity and heat. However, this involves the significant increase of fire and explosion hazard in the coaling system - designed for work with coal, a material with much better parameters characterizing this hazard, than biomass. The article presents the standardized research techniques (applied test stands and methodology) used to determine the data necessary for the design and the application of appropriate measures to reduce fire and explosion hazard related to operation of a mix of coal and biomass.
\end{abstract}

\section{Introduction}

The basic rules for the prevention of explosion and explosion protection include avoiding explosive atmospheres, avoiding any possible effective sources of ignition and limiting the effects of an explosion to an acceptable level [1,2].

Correct assessment of the explosion hazard in accordance with [3] and the selection of appropriate (applicable in a given case) preventive and protective measures requires the determination of the properties of a mixture of a combustible substance with air, informing about the possibility of starting the explosion and behaviour of substances during combustion. The following indicators inform about these properties:

- explosion limits,

- limiting oxygen concentration,

- minimum ignition energy,

- minimum ignition temperature of dust - air mixture,

- minimum ignition temperature of dust layer,

- maximum explosion pressure,

\footnotetext{
* Corresponding author: mwolinski@sgsp.edu.pl
} 
- maximum rate of pressure rise due to explosion.

\section{Determination of flammable properties}

The application of the principle of preventing the explosion by avoiding explosive atmospheres requires knowledge when the mixture has an explosive composition, and when not. This distinction can be made due to the content of flammable dust in the mixture or due to the oxygen content in the mixture. The critical parameter in the first case is the lower explosive limit LEL of combustible dust, while in the second - the limiting concentration of oxygen LOC in the mixture of dust - air - inert gas.

Determination of the lower explosive limit LEL is carried out in a laboratory test in accordance with PN-EN 14034-3 [4]. This standard provides for tests in a spherical or cylindrical chamber with a volume of $1 \mathrm{~m}^{3}$ or - with a volume of $20 \mathrm{dm}^{3}$ (Fig. 1). The main components of the test equipment are: test chamber (capable of withstanding a minimum pressure of 20 bar, dust dispersion system, ignition source (for chamber $1 \mathrm{~m}^{3}$ : two pyrotechnical ignitors with energy $5 \mathrm{~kJ}$ each, for chamber $20 \mathrm{dm}^{3}$ : two fuses with energy $1 \mathrm{~kJ}$ each), a control system, a system for collecting and processing measurement data. The experiment is based on the registration of the pressure course inside the test chamber during the explosion of the dispersed dust sample and subsequent analysis of this record. Research begins with the concentration of dust at which the explosion occurs, and then this concentration is reduced: $1000,750,500,250,125,60,30 \mathrm{~g} / \mathrm{m}^{3}$, until the explosion does not occur. In the case of a test chamber with a volume of $1 \mathrm{~m}^{3}$, the explosion is considered to have occurred if the pressure measured during the experiment exceeds the initial value by at least 0.3 bar, and the concentration at which the explosion did not occur is considered to be the concentration of dust corresponding to the LEL value. In the case of a test chamber with a volume of $20 \mathrm{dm}^{3}$, the criterion is a pressure increase of at least $0.5 \mathrm{bar}$, and the concentration corresponding to the LEL value is the highest concentration of dust, at which the explosion did not occur in three subsequent tests.

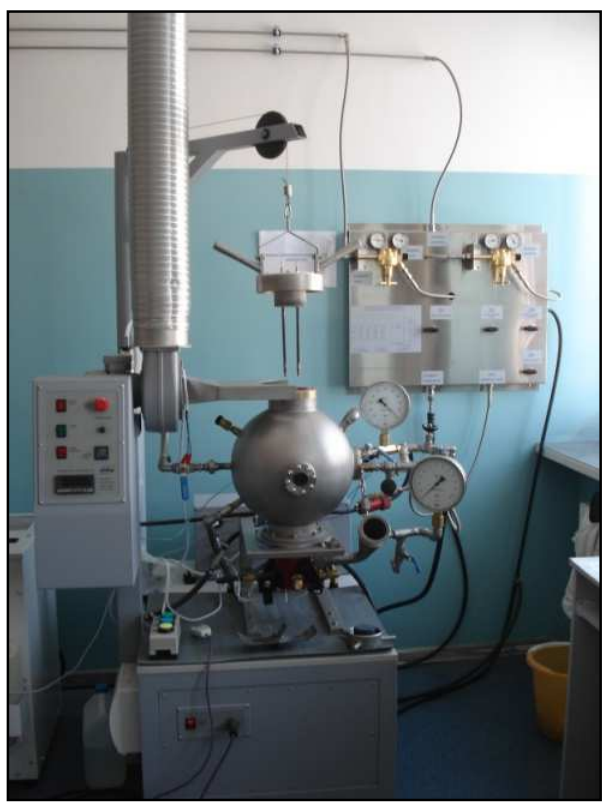

Fig. 1. Spherical test chamber of $20 \mathrm{dm}^{3}$ volume (laboratories of The Main School of Fire Service) 
Determination of the limiting oxygen concentration LOC is carried out in a laboratory test in accordance with PN-EN 14034-4 [5]. The same test chamber is used as in the case of LEL $\left(1 \mathrm{~m}^{3}\right.$ or $\left.20 \mathrm{dm}^{3}\right)$, additionally equipped with a system that allows the inert gas mixture to be supplied to the chamber (with the possibility of changing the oxygen content in this mixture every $1 \%$ by volume, measured with an accuracy of $+0.3 \%$ vol.). The same as for the LEL determination case are the explosion detection criteria for the tested dust concentration and oxygen content in the mixture. The test procedure consists in the step-bystep modification of the oxygen content in the mixture and the concentration of dust, with the same criteria as the LEL determination of the mixture ignition but the LOC value requires confirmation in three consecutive tests for each dust concentration that will not ignite.

\section{Determination of ignition properties}

\subsection{Minimum ignition energy MIE}

The determination of the minimum ignition energy MIE of the air / dust mixture is carried out in a laboratory test in accordance with standard [6], using the test stand shown in Figure 2. The stand is designed for determining the minimum ignition energy of dust cloud at ambient temperature. The dust is lifted by a blast of air and then ignition attempt is performed by charging a high voltage spark with known energy value. The minimum energy used to ignite a dust cloud is considered to be the lowest energy determined for the current research.

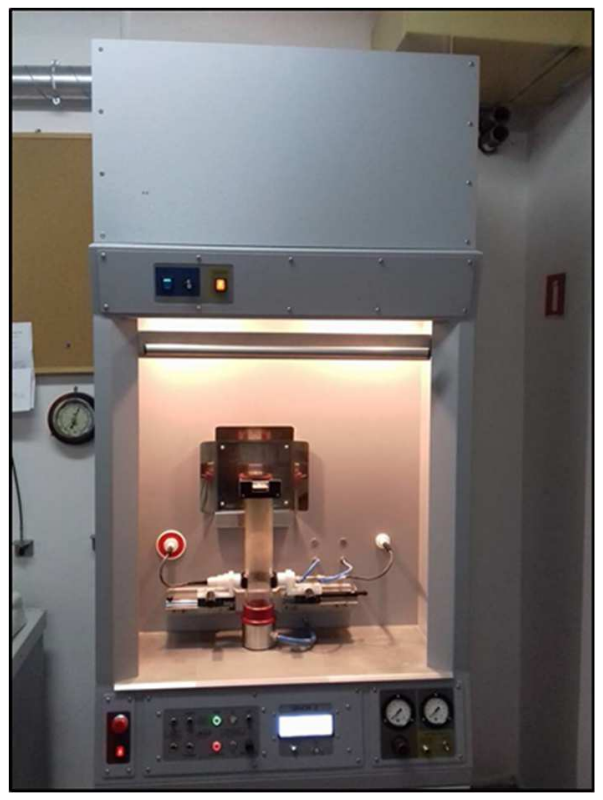

Fig. 2. Test stand for MIE determination of dust - air mixtures (laboratories of The Main School of Fire Service)

The main part of the stand is a 1.2-liter Hartmann glass tube. The stand construction enables the energy of $1000 \mathrm{~mJ}, 300 \mathrm{~mJ}, 100 \mathrm{~mJ}, 30 \mathrm{~mJ}, 10 \mathrm{~mJ}, 3 \mathrm{~mJ}$ and $1 \mathrm{~mJ}$ of spark to be applied, with an ignition delay time in the range of $50-350 \mathrm{~ms}$. During the test, the dust sample dispersed in the glass Hartmann tube is ignited with the high voltage spark. Adjusted energy value is stored in the capacitor and discharged during the ignition process. Dust 
ignition is evaluated visually by the operator. The test result is the lowest ignition energy obtained for a given dust (of characteristic particle size and moisture content), defined as:

$$
E_{1}<M I E<E_{2}
$$

where:

$E_{1} \quad-\quad$ the highest energy at which ignition does not occur,

$E_{2} \quad-\quad$ the lowest energy at which ignition occurs in one of the next 10 trials.

The energy value stored in the capacitor is calculated from the equation:

$$
E=0.5 \cdot C \cdot U^{2}
$$

where :

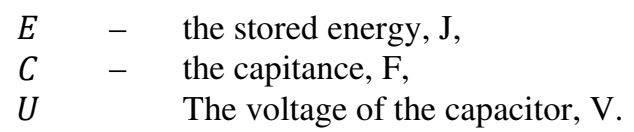

\subsection{Minimum ignition temperature of dusty explosive mixture}

Determination of the minimum ignition temperature of dusty explosive atmosphere is carried out according to the standard [7], method B: cloud of dust in a constant temperature furnace (test stand: Fig.3). This method is used to indicate the minimum temperature at which the cloud of a tested dust or other particulate solid is ignited. The test consists in observing whether an ignition of a sample of dust injected into the furnace at a specified temperature occurred. It is considered that the ignition occurred if the burst of flame is visible beyond the lower end of the furnace pipe. A certain ignition delay is allowed. Sparks without a flame do not constitute ignition. The minimum ignition temperature of the dust cloud should be the lowest temperature of the furnace where the ignition has been achieved using a standard measurement procedure with changing the dust sample mass and pressure of the dispersing air as well as furnace temperature, reduced by $20 \mathrm{~K}$ at furnace temperature above $300^{\circ} \mathrm{C}$ and $10 \mathrm{~K}$ at furnace temperature equal to $300^{\circ} \mathrm{C}$ or lower. If at the temperature of the furnace even up to $1000^{\circ} \mathrm{C}$ ignition was not obtained, this fact should be noted in the test report.

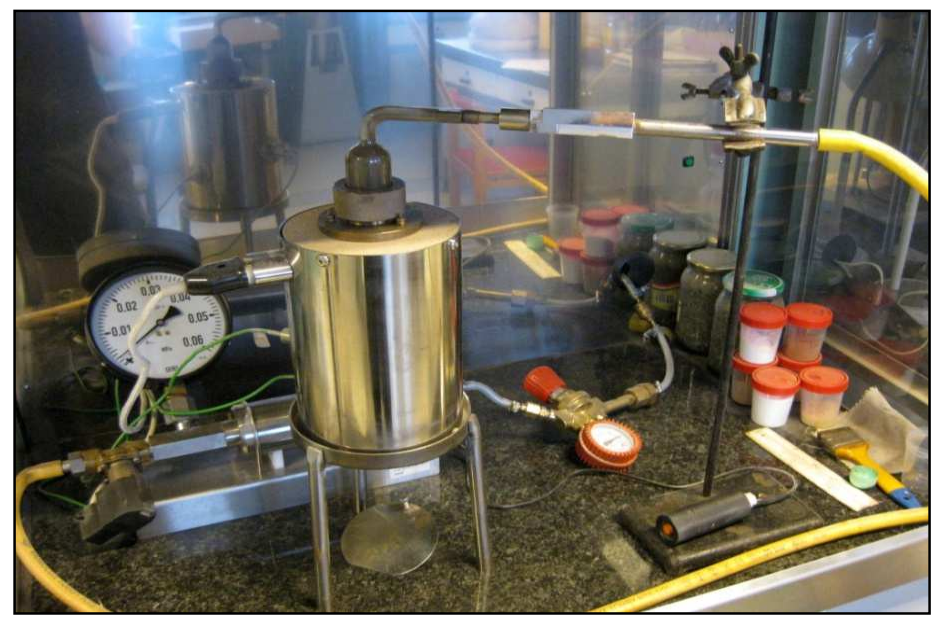

Fig. 3. Test stand (oven) for determination of minimum ignition temperature of dust cloud (laboratories of The Main School of Fire Service) 


\subsection{Minimum ignition temperature of dust layer}

Determination of the minimum ignition temperature of the dust layer is carried out according to the standard [7], method A (test stand: Fig. 4). This method is used to determine the minimum temperature at which the dust layer of a specific thickness placed on the hotplate reaches decomposition and /or ignition. This method applies in particular to industrial equipment with hot surfaces, where dust forms thin layers and is exposed to atmospheric air. The test consists in observing whether a sample of dust, formed and kept in a suitable way on the heating plate ignites or not. It should be considered that the ignition occurred if:

- glow or smoking has been observed, or

- the measured temperature of the dust sample has reached the value of $450^{\circ} \mathrm{C}$, or

- the measured temperature of the dust sample has exceeded the temperature of the heating plate by $250 \mathrm{~K}$.

In order to determine the minimum ignition temperature of a dust layer of a certain thickness, a series of tests should be carried out using a new dust sample in each test. The temperature of the heating plate should be changed accordingly until the temperature that ignites the layer is found, higher not more than $10 \mathrm{~K}$ from the temperature which did not lead to the ignition of the layer (it should be confirmed in at least three tests).

The highest temperature at which ignition has not occurred should be confirmed by continuing the test long enough to be able to conclude that the self-heating rate is decreasing, i.e. the temperature at the measurement point in the layer falls to a predetermined value, lower than the temperature of the heated surface. The tests should be interrupted if ignition of the dust layer does not occur at the temperature of the heating plate up to $400^{\circ} \mathrm{C}$.

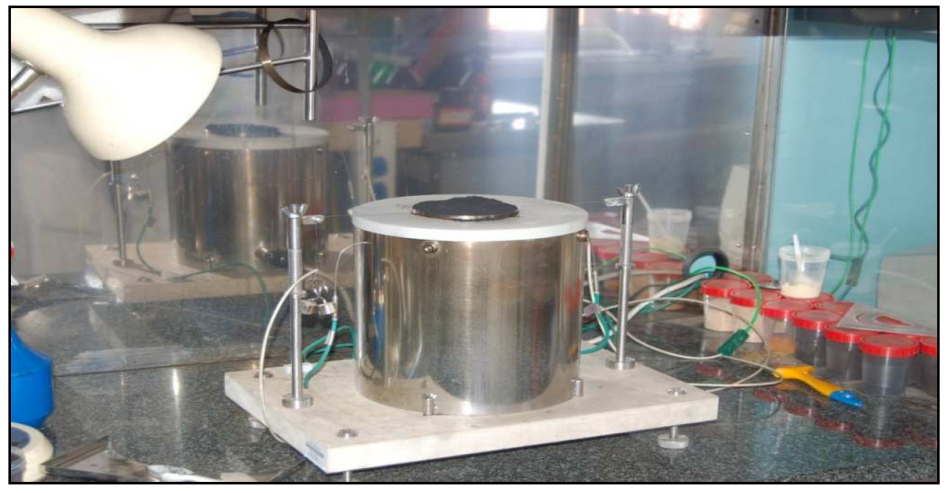

Fig. 4. Test stand for determination of minimum ignition temperature of dust layer (laboratories of The Main School of Fire Service)

\subsection{Determination of the spontaneous ignition behaviour of dust accumulations}

Determination of the spontaneous ignition behaviour of dust accumulations is carried out in accordance with standard [8] (standard [9] applies only to hard coal). This standard specifies testing and evaluation procedures for determining the self-ignition temperature of combustible dust as a function of volume by means of hot storage experiments in a constant temperature furnace (test stand: Fig. 5). If the test is carried out at temperatures well below the self-ignition temperature of the dust to be examined, the sample temperature reaches asymptotically the temperature of the furnace. At higher temperatures of the furnace reactions with oxygen are clearly visible in the sample material. For this reason, the sample temperature 
will be temporarily higher than the furnace temperature. This indicates that self-heating processes have started, without the spontaneous ignition of the sample. There are two ways to determine if the ignition occurs:

- when the temperature inside the sample rises by at least $60 \mathrm{~K}$ above the furnace temperature,

- when the temperature course inside the sample as a function of time shows an inflection point, if this occurs above the furnace temperature.

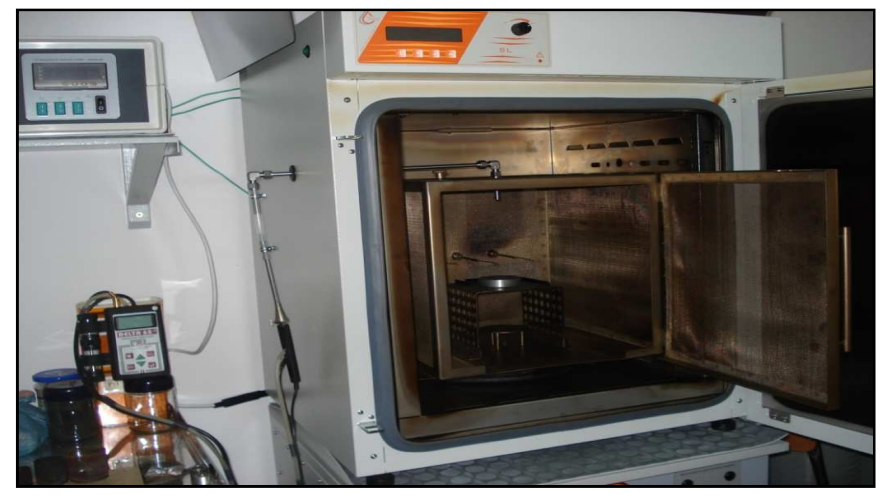

Fig. 5. Test stand for determination of the spontaneous ignition behaviour of dust accumulations (laboratories of The Main School of Fire Service)

The choice of hot storage temperatures for the two final critical tests should be made in such a way that the temperature of the furnace causing the ignition and the temperature of the furnace not causing ignition differ by no more than $5 \mathrm{~K}$. The result of the self-ignition temperature measurements is rounded down to the nearest integer value expressed in degrees.

\section{Determination of properties characterizing the explosion course}

The standard [10] indicates that the calculated size of the venting surface depends, among others, on two parameters describing an explosive dust/air mixture: the maximum explosion pressure $\mathrm{p}_{\max }$ and the $\mathrm{K}_{\mathrm{St}}$ coefficient (i.e. practically on the value of the maximum rate of explosion pressure rise $\left.(\mathrm{dp} / \mathrm{dt})_{\max }\right)$.

The value of the maximum explosion pressure $\mathrm{p}_{\max }$ of the dust/air mixture is determined in laboratory tests in accordance with the standard [11], using the same test chamber as for the determination of the LEL and LOC values (Figure 1). The standard recommends tests for a number of concentrations of dust in the mixture: $60,125,250,500,750,1000,1250,1500$ $\mathrm{g} / \mathrm{m}^{3}$ and - for the $20 \mathrm{dm}^{3}$ chamber, it provides a method of calculating the $p_{\max }$ value and correcting this value due to cooling effect of chamber walls as well as impact of explosion pressure of pyrotechnical igniters.

The value of the maximum rate of explosion pressure rise $(\mathrm{dp} / \mathrm{dt})_{\max }$ is determined in accordance with standard [12], using a similar test procedure as for $\mathrm{p}_{\max }$ (also for the same series of dust concentrations in mixture), and the $\mathrm{K}_{\mathrm{St}}$ value is calculated as:

$$
K_{S t}=(d p / d t)_{\max } * V^{1 / 3}
$$

where :

$V \quad-\quad$ the test chamber volume, $\mathrm{m}^{3}$. 


\section{Conclusion}

Correct assessment of the explosion hazard and the selection of appropriate (possible to apply in a given case) preventive and protective measures requires the determination of the properties of a mixture of a combustible substance with air, informing about the possibility of starting the explosion and the behavior of substances during combustion. Conducting normative tests described above (and systematized recently by [13]) allows to determine safety data - appropriate parameters describing these properties. However, it should be borne in mind that this type of safety data are not physical constants - they depend on the size and shape of the dust particles, the moisture content and the presence of additives even in trace amounts. Therefore, in order to identify hazards and to determine preventive and protective measures, it is necessary to test dusts collected in specific places and operating conditions of equipment in the technological process.

\section{References}

1. PN-EN 1127-1:2001 Atmosfery wybuchowe. Zapobieganie wybuchowi i ochrona przed wybuchem. Pojęcia podstawowe i metodologia.

2. Rozporządzenie Ministra Gospodarki z dnia 8 lipca 2010 r. w sprawie minimalnych wymagań, dotyczących bezpieczeństwa i higieny pracy, związanych z możliwością wystąpienia w miejscu pracy atmosfery wybuchowej. Dz. U. z 30 lipca 2010 Nr 138 poz. 931.

3. PN-EN 60079-10-2:2015 Atmosfery wybuchowe - Część 10-2: Klasyfikacja przestrzeni. Pyłowe atmosfery wybuchowe.

4. PN-EN 14034-3:2011 Oznaczanie charakterystyk wybuchowości obłoków pyłu - Część 3: Oznaczanie dolnej granicy wybuchowości DGW obłoków pyłu.

5. PN-EN 14034-4:2011 Oznaczanie charakterystyk wybuchowości obłoków pyłu - Część 4: Oznaczanie granicznego stężenia tlenu GST obłoków pyłu.

6. PN-EN 13821: 2004 Przestrzenie zagrożone wybuchem. Zapobieganie i ochrona przed wybuchem. Oznaczanie minimalnej energii zapłonu mieszanin pyłowo - powietrznych.

7. PN-EN 50281-2-1:2002 Urządzenia do stosowania w obecności pyłów palnych - Część 2-1: Metody badania. Metody oznaczania minimalnej temperatury zapłonu pyłu.

8. PN-EN 15188:2009 Oznaczanie skłonności nagromadzeń pyłu do samozapalenia.

9. PN-G-04558:1993 Węgiel kamienny - Oznaczanie wskaźnika samozapalności.

10. PN-EN 14491:2013 Systemy ochronne odciążające wybuchy pyłów.

11. PN-EN 14034-1:2011 Oznaczanie charakterystyk wybuchowości obłoków pyłu - Część 1: Oznaczanie maksymalnego ciśnienia wybuchu pmax obłoków pyłu.

12. PN-EN 14034-2:2011 Oznaczanie charakterystyk wybuchowości obłoków pyłu - Część 2: Oznaczanie maksymalnej szybkości narastania ciśnienia wybuchu (dp/dt)max obłoków pyłu.

13. PN-EN ISO/IEC 80079-20-2:2016 Atmosfery wybuchowe - Część 20-2: Właściwości materiałowe. Metody badań pyłów palnych. 